\title{
Women's clothing with eco design features
}

\author{
Radka Atanasova ${ }^{1, *}$ \\ ${ }^{1}$ Technical University of Sofia, Department of Textiles, 1000 Sofia, Bulgaria
}

\begin{abstract}
In the paper, women's wear with eco design features is created and manufactured. The object of the study is a dress in a semi-slim silhouette. The patterns of the garment are constructed automatically using a specialized CAD system. Algorithms for geometric construction of pieces and production patterns have been developed. The technology for manufacturing the dress has been composed. Markers for robotic cutting of the articles are planned. Three dresses are sewn. Each dress is decorated differently with elements cut from the fabric waste. The result of the proposed approach is three styles of clothing with three different unique looks with minimized textile waste. The artistic design of clothing with eco features demonstrates creative approach and good textile knowledge on the various methods of design and technological processing of materials. Using the fabric waste after cutting requires innovative thinking in order to make the garment attractive and to be preferred by a wider range of consumers. The production and successful sale of eco-friendly clothing occupies a worthy niche in the market.
\end{abstract}

\section{Introduction}

The rapid development of the industry worldwide generates many environmental problems. Mass exploitation and overproduction of goods cause enormous damage on the environment. Insufficient recycling of waste products from manufacturing leads to pollution of the planet. The fashion industry as an intensively developing sector of industry is among the five biggest polluters of the environment, along with the extraction of fuels. At the same time, fashion is fast-changing. It is estimated that 100 billion garments are produced worldwide each year.

To secure a sustainable future, the big fashion brands are looking for solutions to the ecological crisis [4]. Fashion design is increasingly focused on eco and organic fashion. This is the most innovative and seeking part of fashion, which allows customers to wear avantgarde clothing. It is addressed to a new generation of environmentally and socially responsible consumers, for whom both the design and the production path of the garment and the long-term consequences of its manufacture are equally important. These consumers with their clothing show their responsible attitude to the global environmental problems caused by the fashion industry and textile waste. By choosing eco-clothing for their wardrobe, they manage to declare their own style in a unique way.

\footnotetext{
*Radka Atanasova: ratanasova@tu-sofia.bg
} 


\section{Methods and Results}

The object of the study is ladies' dress in a semi-slim silhouette. The model of the dress is presented with a technical sketch on Fig. 1. The dress is separated at the waist. The length of the dress along the middle seam of the back is $90.0 \mathrm{~cm}$. The front part above the waist line consists of three details and has princess seams that start from the point under the arm. The bottom part is like a straight skirt with waist darts. The back top part consists of four details and has princess seams that start at $6.0 \mathrm{~cm}$ along the armhole curve down. The fastening has a hidden zipper in the middle seam on the back. The bottom back part has waist darts and a slit with a length of $16.0 \mathrm{~cm}$. The neck line is slightly deepened. The collar is a band type without overlapping with a width of $4.0 \mathrm{~cm}$. The sleeve is short with a length of $5.0 \mathrm{~cm}$ along the inner seam. Since the details are symmetrical, we work on the halves of them.
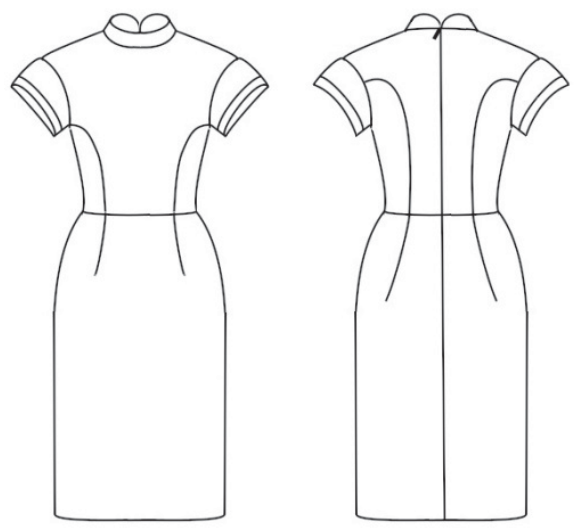

Fig. 1. Technical sketch of the model.

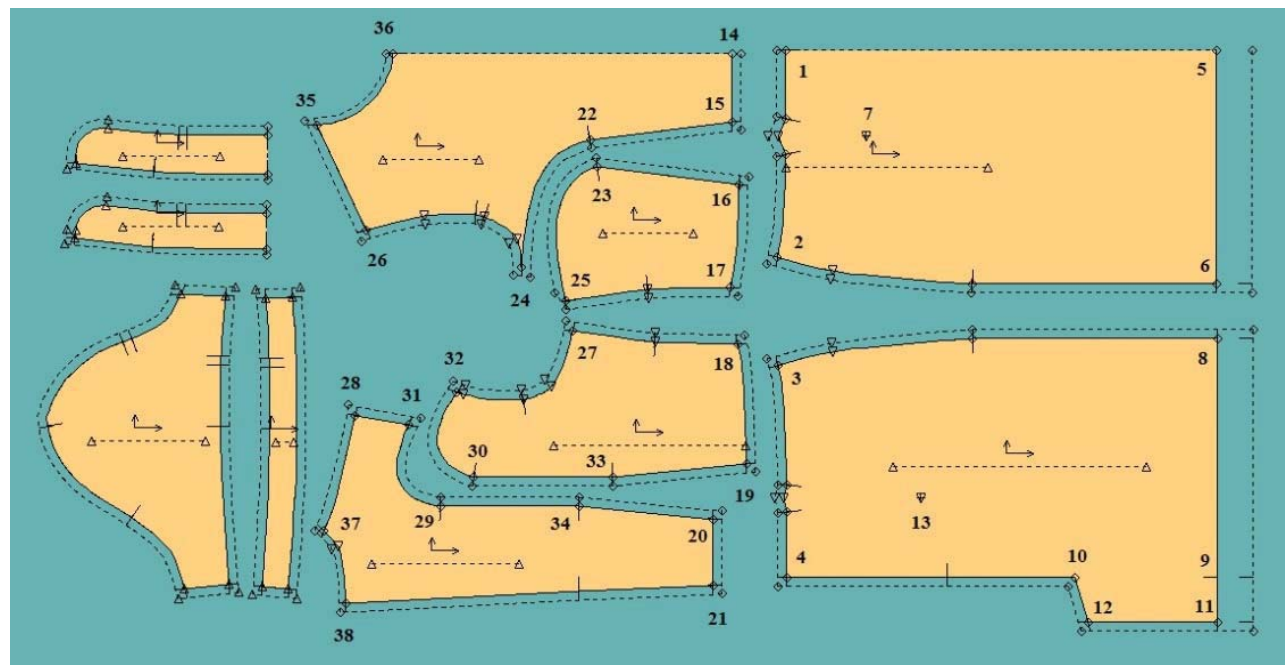

Fig. 2. Construction drawing of the pieces. 


\subsection{Construction of the patterns}

The patterns of the garment are constructed automatically applying a specialized CAD system. The present development uses the functions [3] of the program AccuMark, version 10 of the company Gerber Technology, USA. Algorithms for geometric construction of pieces and production patterns in a graphical environment have been developed.

The base construction for size 44 BG (164/88/96) with a single-seam sleeve and a band collar was designed according to the methodology [2]. In Table 1, an exemplary algorithm for construction modeling has been proposed. To model the main part of the garment on the screen, the front and back pieces are opened, named BASE DRESS FR and BASE DRESS BK, respectively. The sleeve is developed on the basis of DRESS SLEEVE piece. A table with the sizes of the details Rule Table: BG-LADIES, including sizes from 42 to 52, have been created, according to which the dress can be graded if necessary. The production patterns for sewing the model are given on Fig. 2.

Table 1. Algorithm for construction modeling.

\begin{tabular}{|c|c|c|c|}
\hline No & Name of the step & $\begin{array}{c}\text { Function in CAD } \\
\text { system }\end{array}$ & $\begin{array}{c}\text { Parameters/ } \\
\text { Elements of the } \\
\text { drawing } \\
\end{array}$ \\
\hline 1 & 2 & 3 & 4 \\
\hline 1 & $\begin{array}{c}\text { Separating the front and back piece along the } \\
\text { waist line }\end{array}$ & $\begin{array}{l}\text { Modify/Piece Act/ } \\
\text { Split on Dig Ln }\end{array}$ & $\begin{array}{l}\text { FR: } 1-2 \\
\text { BK: } 3-4\end{array}$ \\
\hline 2 & $\begin{array}{l}\text { Defining the waist and bust darts for top and } \\
\text { bottom parts }\end{array}$ & $\begin{array}{l}\text { Modify/Ln Act/ } \\
\text { Replace }\end{array}$ & \\
\hline 3 & Merging the dart legs & $\begin{array}{l}\text { Modify/Ln Act/ } \\
\text { Combine }\end{array}$ & \\
\hline 4 & Transforming the merged lines into darts & $\begin{array}{l}\text { Advanced/Darts/ } \\
\text { Convert }\end{array}$ & \\
\hline 5 & $\begin{array}{l}\text { Adjusting the length of the dart legs in the } \\
\text { bottom front and back parts }\end{array}$ & $\begin{array}{l}\text { Advanced/Darts/ } \\
\text { Manipulate/ } \\
\text { Change Dart Tip }\end{array}$ & $\begin{array}{l}\text { FR/ Dist: } 9,0 \mathrm{~cm} \\
\text { BK/ Dist: } 14,0 \mathrm{~cm}\end{array}$ \\
\hline 6 & $\begin{array}{l}\text { Designing a slit in the middle seam of the } \\
\text { back }\end{array}$ & $\begin{array}{l}\text { 1. Modify/Ln Act/ } \\
\text { Split } \\
\text { 2. Create/Ln/ } \\
\text { Offset Even } \\
\text { 3. Create/Ln/ } \\
\text { 2 Pt/ } 2 \mathrm{Pt} \\
\text { 4. Modify/Ln Act/ } \\
\text { Swap }\end{array}$ & $\begin{array}{l}\text { Beg: } 16,0 \mathrm{~cm} \\
\text { Dist: } 5,0 \mathrm{~cm} \\
\text { Beg: } 15,0 \mathrm{~cm}\end{array}$ \\
\hline 7 & $\begin{array}{l}\text { Moving the dart tip for the waist dart of the } \\
\text { top front part }\end{array}$ & $\begin{array}{l}\text { Advanced/Darts/ } \\
\text { Manipulate/ } \\
\text { Change Dart Tip }\end{array}$ & $\mathrm{X}: 3,0 \mathrm{~cm}$ \\
\hline 8 & $\begin{array}{c}\text { Designing a curve for princess seam of the } \\
\text { front part }\end{array}$ & $\begin{array}{l}\text { Create/Ln/ } \\
2 \mathrm{Pt} / 2 \mathrm{Pt} \text { Curve }\end{array}$ & $23-25$ \\
\hline 9 & $\begin{array}{l}\text { Rotating the bust dart to the point under the } \\
\text { arm for the front part }\end{array}$ & $\begin{array}{l}\text { Advanced/Darts/ } \\
\text { Manipulate/Rotate }\end{array}$ & $24-22-25$ \\
\hline 10 & $\begin{array}{l}\text { Shaping the upper slope of the princess seam } \\
\text { for the front part }\end{array}$ & $\begin{array}{c}\text { 1. Create/Ln/ } \\
\text { Copy } \\
\text { 2. Modify/Ln Act/ }\end{array}$ & $\begin{array}{c}\text { Select Ref } \\
\text { Location: } 25 \rightarrow 24\end{array}$ \\
\hline
\end{tabular}




\begin{tabular}{|c|c|c|c|}
\hline 1 & 2 & 3 & 4 \\
\hline & & $\begin{array}{l}\text { Rotate } \\
\text { 3. Modify/Pt Act/ } \\
\text { Move Pt } \\
\text { 4. Verify/ } \\
\text { Ln Length } \\
\text { 5. Modify/Ln Act/ } \\
\text { Length }\end{array}$ & $\begin{array}{l}18,2 \mathrm{~cm} \\
17,7 \mathrm{~cm}\end{array}$ \\
\hline 11 & $\begin{array}{c}\text { Designing a curve for princess seam of the } \\
\text { back part }\end{array}$ & $\begin{array}{l}\text { Create/Ln/ } \\
2 \mathrm{Pt} / 2 \mathrm{Pt} \text { Curve }\end{array}$ & $30-32$ \\
\hline 12 & $\begin{array}{l}\text { Rotating the shoulder dart to the armhole for } \\
\text { the back part }\end{array}$ & $\begin{array}{l}\text { Advanced/Darts/ } \\
\text { Manipulate/Rotate }\end{array}$ & $31-29-32$ \\
\hline 13 & $\begin{array}{c}\text { Shaping the upper slope of the princess seam } \\
\text { for the back part }\end{array}$ & $\begin{array}{l}\text { 1. Create/Ln/ } \\
\text { Copy } \\
\text { 2. Modify/Ln/ } \\
\text { Rotate } \\
\text { 3. Modify/Pt Act/ } \\
\text { Move Pt } \\
\text { 4. Verify/ } \\
\text { Ln Length }\end{array}$ & $\begin{array}{c}\text { Select Ref } \\
\text { Location: } 32 \rightarrow 31 \\
\text { Bump to Ln: } 30-32\end{array}$ \\
\hline 14 & $\begin{array}{l}\text { Deepening the neck line of the front and back } \\
\text { pieces }\end{array}$ & $\begin{array}{l}\text { Create/Ln/ } \\
\text { Offset Uneven }\end{array}$ & $\begin{array}{l}\text { Shoulder: }-1,0 \mathrm{~cm} \\
\text { Center FR: }-0,5 \mathrm{~cm} \\
\text { Center BK: }-0,5 \mathrm{~cm}\end{array}$ \\
\hline 15 & $\begin{array}{c}\text { Output of the separate pieces from the general } \\
\text { drawing }\end{array}$ & $\begin{array}{l}\text { Create/Piece/ } \\
\text { Trace }\end{array}$ & Piece Name: \\
\hline 16 & Adding seam allowance and hem & $\begin{array}{l}\text { Advanced/Seam/ } \\
\text { Define }\end{array}$ & $\begin{array}{l}1,0 \mathrm{~cm} \\
4,0 \mathrm{~cm}\end{array}$ \\
\hline 17 & Placing notches for assembling the details & $\begin{array}{l}\text { Create/Notch/ } \\
\text { Standard } \\
\text { Advanced/Seam/ } \\
\text { Regular Corner }\end{array}$ & \\
\hline
\end{tabular}

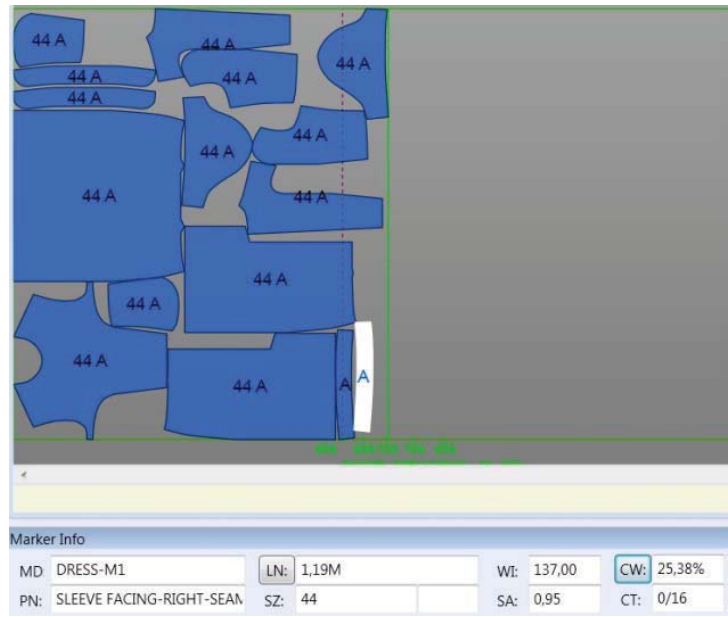

Fig. 3. Marker for robotic cutting. 


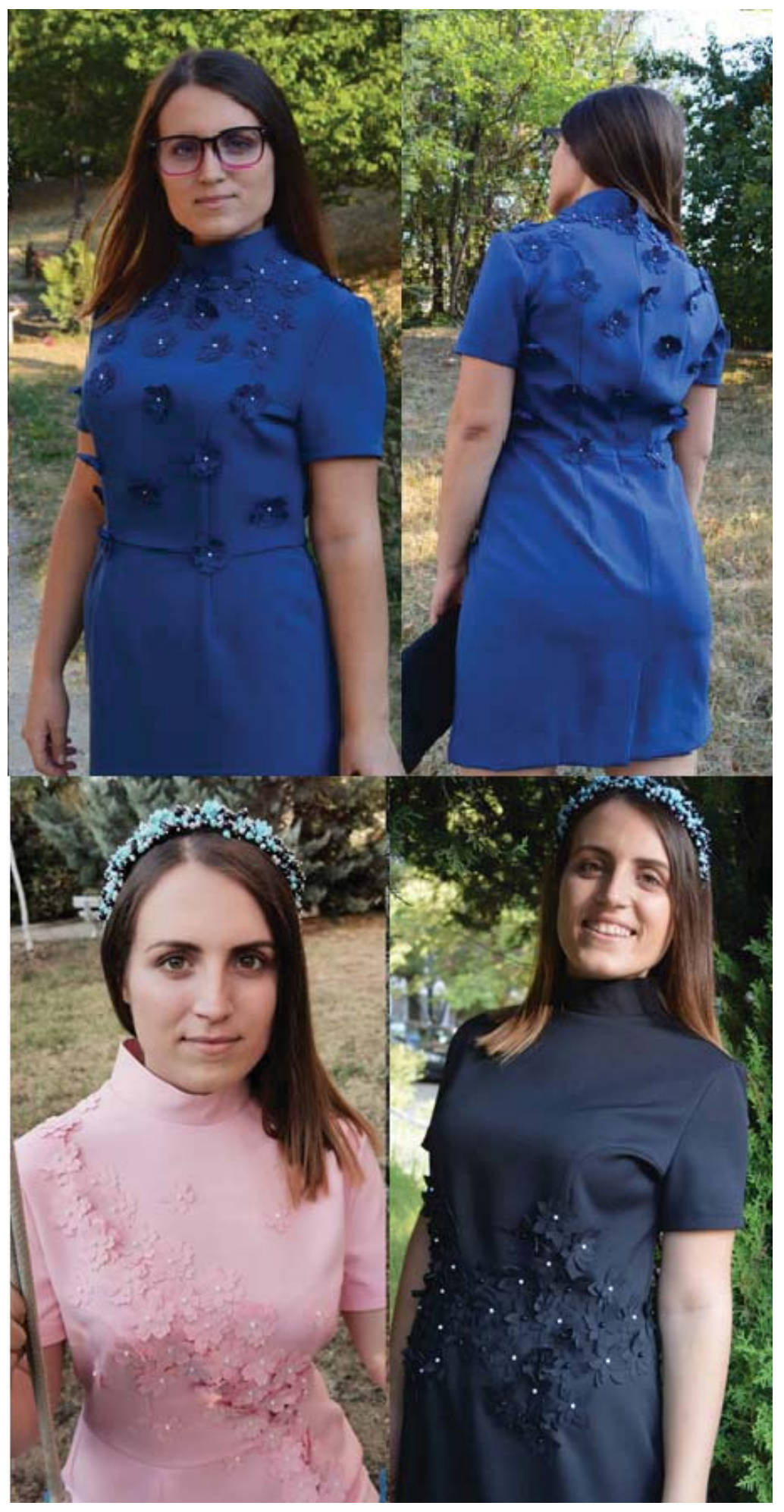

Fig. 4. Finished dresses with decoration elements cut from the fabric waste. 


\subsection{Markers for cutting}

Six markers are planned, composed respectively of the details for 1 to 6 dresses. The width of the fabric without edges is $137,0 \mathrm{~cm}$. The fabric is made of $95 \%$ cotton and $5 \%$ elastomer. The markers are generated automatically with the AutoMark Editor software, under the following restrictive conditions: Placement strategy: Length, Effort: 10\%. The experiment shows that in this configuration of the production patterns, the cost rate of fabric per unit of product is the lowest for two dresses in the marker- $1,14 \mathrm{~m}$, in case of internal waste $22,80 \%$. This option is recommended for serial production.

Because of the designer's requirement for the experimental products to be different in colour, the marker for one product at a length of 1,19 $\mathrm{m}$ (an internal waste of 25,38\%) was chosen for robotic cutting the dresses (Fig. 3). The fabrics are spread from dark to bright, because there is a threat that threads from the upper layers will fall on the lower layers when cutting. A technology for manufacturing the dress in tabular form has been composed with the name of the operation, used equipment, seam scheme [1]. Three identical dresses are sewn.

\subsection{Ideas for decoration of dresses}

Before the stage of decorating, the dresses in this article differ only in color. Eco design is achieved by using the cutting waste of the fabric to decorate the products. Using a laser knife, three types of flowers in three different sizes are cut from the waste. The flowers vary in the shape of the leaf. The amount of waste allows 60 pieces of each type and size to be cut.

The dresses are decorated by hand sewing three identical flowers on top of each other from large to small in combination with beads. Each of the dresses is decorated according to a different arrangement of flowers. The result of the proposed approach is three styles of clothing with three different unique looks, which can be seen on Fig. 4.

\section{Conclusions}

In the present development, three models of women's dresses with decoration have been created and manufactured. The patterns of the garment are developed using the functions of a specialized apparel CAD system. Algorithms for geometric construction of details in a graphical environment are proposed. The planned markers for cutting the products provide a choice of working with the lowest possible percentage of waste. To further reduce the textile waste from cutting, it is used to cut elements with which the sewn dresses are decorated. As a result from one construction and on the same manufacturing technology, three garments with eco-design features were obtained and three different visions are achieved.

Artistic design of clothing with eco features demonstrates good textile knowledge on the various methods of design and technological processing of materials. Using the fabric waste after cutting requires creative thinking in order to make the garment attractive and to be preferred by a wider range of consumers. The production and successful sale of ecofriendly clothing occupies a worthy niche in the market.

\section{References}

1. P. Ilieva, Design of women's clothing with eco-design features, diploma thesis, Sofia (2019) 
2. H. Petrov, Clothing design, Publisher TU of Sofia, (2009)

3. AccuMark Professional Edition. What is new for AccuMark V10.0, Gerber Technology Inc., a Business Unit of Gerber Scientific International (2015)

4. https://fibertechinc.net/sustainable-clothing/, Accessed on date 30 October, 2020 